\title{
RELIGIA JAKO DUCHOWY AUTOEROTYZM CZY LOGOCENTRYCZNA POSTAWA WIARY? KONSEKWENCJE OSOBOWEGO ROZUMIENIA ABSOLUTU W TEOLOGII J. RATZINGERA
}

\section{WPROWADZENIE - POSTAWIENIE PROBLEMU}

W wywiadzie dla dziennika „L'Express” Joseph Ratzinger określił buddyzm jako rodzaj duchowego autoerotyzmu (autoérotisme spiritual), wskazując, że siłą tej formy religijności jest obietnica szczęścia ${ }^{1}$. Aby

* Olaf Szczypiński, magister teologii i prawa, licencjat kanoniczny; aktualnie pracuje nad doktoratem z pogranicza teologii fundamentalnej, teologii pastoralnej oraz filozofii przy Katedrze Prawa Kanonicznego i Filozofii na Wydziale Teologii Uniwersytetu Warmińsko-Mazurskiego w Olsztynie. Autor kilku rozdziałów w monografiach oraz czasopismach punktowanych dotyczących teologii J. Ratzingera/Benedykta XVI oraz z zakresu nauk o rodzinie (olafszczyp@gmail.com).

1 "Si le bouddhisme séduit, c'est parce qu'il apparaît comme une possibilité de toucher à l'infini, à la félicité sans avoir d’obligations religieuses concrètes. Un autoérotisme spirituel, en quelque sorte. Quelqu'un avait justement prédit, dans les années 50, que le défi de l'Eglise au XXe siècle serait non pas le marxisme, mais le bouddhisme", Le testament du Panzerkardinal Ratzinger, „L'Express”, 20 III 1997, http://www.lexpress. fr/informations/le-testament-du-panzerkardinal_621444.html. 
zrozumieć tę wypowiedź, należy, oprócz uwag z dalszej części artykułu dotyczących relacji religii do zbawienia i dialogu międzyreligijnego, sięgnąć do źródeł, w których Ratzinger bezpośrednio traktuje o buddyzmie. Niestety nie ma w jego badaniach systematycznego opracowania tego zagadnienia. Kontekst ten pojawia się zawsze wtedy, gdy uzasadnia on wiarę chrześcijańską. Jest to zabieg argumentacji ad intra, próbujący uzasadnić sens depozytu chrześcijaństwa. Na jego podstawie można sformułować kilka uwag wprowadzających.

Po pierwsze, trzeba pamiętać, że nie można wyjaśniać znaczenia religii azjatyckich przez pojęcie „religii” utożsamiane jedynie z religiami, które wpisały się w kulturę Zachodu². Tym samym wysiłki filozofii religii, zmierzające do uogólniania pojęć, muszą z konieczności zawodzić.

Po drugie, religia teistyczna ma osobowy charakter, co oznacza, że zwieńczeniem hierarchii bytów, czyli Boskością, jest osoba. Religijność azjatycka natomiast umieszcza Absolut poza sferą bytów osobowych, co wynika z pragnienia rezygnacji z istnienia będącego źródłem cierpienia i podążaniem ku czystej „nicości”3.

Ta nieco szersza perspektywa wypowiedzi Ratzingera ukazuje istotne, $\mathrm{z}$ religijnego punktu widzenia, problemy. Jeżeli przyjąć, że podstawowym celem każdej religii jest zbawienie, rozumiane jako pewna forma szczęśliwości, to pojawia się dylemat: czy jest ono darem Absolutu, czy też jest oddolną, indywidualną drogą człowieka? Dwie możliwe interpretacje zbawienia wyznaczają zarazem linię demarkacyjną między wiarą a kultem, rozumianym jako „religijne postępowanie” w sferze ludzkiej. Jeżeli natomiast spojrzeć na dialog religii z punktu widzenia soteriologii chrześcijańskiej, to na pierwszy plan wysuwa się zasadniczy problem dotyczący zbawienia niechrześcijan. Innymi słowy, czy według wiary chrześcijańskiej wyznawcy innych religii będą zbawieni. W jego zakres wpisuje się zagadnienie podane $\mathrm{w}$ tytule, które można ująć $\mathrm{w}$ postaci pytań: czy

2 J. Ratzinger, Problem absolutności chrześcijańskiej drogi zbawienia, [w:] tenże, Joseph Ratzinger Opera Omnia, Lublin 2013 i n. (dalej jako: JROO), t. VIII, s. 962: „Ateistyczna religia buddyzmu broni się przed włączaniem jej w taką lub inną wspólną definicję $\mathrm{z}$ teistycznymi typami religii Zachodu. I nikt nie ma prawa nazywać 'religią' jedynie typów zachodnich, do czego mamy skłonność”.

3 Tamże. 
wiara w ujęciu Ratzingera jest tylko formą umysłowej gry prowadzącej do afirmacji samego siebie, a tym samym ograniczającą obecność zbawienia, które w swej istocie zakłada działanie Absolutu? Tak postawione zagadnienie prowadzi w konsekwencji do drugiego: czy osobowa wizja Absolutu jest przejawem racjonalności wiary, który odróżnia wiarę monoteistyczną od wiary mistycznej? Zasadniczo są to więc pytania o naturę Absolutu oraz o relacje wiary chrześcijańskiej wobec niechrześcijan.

Artykuł podzielony jest na trzy części. Pierwsza to ścisłe przedstawienie Kościoła i religii w relacji do zbawienia - a więc miejsca, jakie zajmuje Kościół, oraz jaka jest jego misja w świecie w odniesieniu do innych religii. Następnie analizie poddana została kwestia dialogu religii, ze wskazaniem jego założeń. Część trzecia dotyczy różnych aspektów osobowego i nieosobowego pojęcia Absolutu, a w szczególności uwag dotyczących jego obrazu w buddyzmie i związanych z tym problemów interpretacyjnych. Wskazanie różnic stanowi zarazem syntezę przeprowadzonej w początkowych częściach analizy. Poniższy szkic nie rości sobie pretensji do wyczerpania zagadnienia. Jest to jedynie próba dodania kilku elementów do wspólnego dialogu, które za pomocą sformułowań ukształtowanych przez Ratzingera ukierunkują problem w stronę poszukiwania nowych akcentów.

\section{KOŚClÓł I RELIGIE W RELACJI DO ZBAWIENIA}

Zmagania chrześcijaństwa o określenie własnego miejsca w świecie religijnym, których wycinek ma zostać tu przedstawiony z perspektywy Josepha Ratzingera, od samego początku budziły wiele kontrowersji ${ }^{4}$, odsłaniających nowe pytania o wzajemne relacje i sens prowadzonych dysput. Jest to punkt styku chrześcijaństwa oraz religii niechrześcijańskich. Istotnym zadaniem wiary chrześcijańskiej jest określenie swojej pozycji w relacji do religii świata. W sytuacji dialogu religijnego chrześcijaństwo

${ }^{4} \mathrm{~W}$ swoich początkach chrześcijanie byli określani przez politeistów mianem „ateistów”. Rozwiązanie tego problemu przez pryzmat teologii Augustyna pokazuje J. Ratzinger, Lud i dom Boży w nauce św. Augustyna o Kościele, JROO, t. I, s. 39-392; szczególnie zob. s. 60-66, 281-296, 328-338. 
musi przemyśleć swoje roszczenia względem innych wyznań. Proces ten umożliwia oczyszczenie i pozwala lepiej zrozumieć rolę innych religii w historii zbawienia.

Jako klucz do zrozumienia stosunku Ratzingera do religii wschodnich można przyjąć teologiczne uzasadnienie misji i stanowiska Kościoła wobec religii niechrześcijańskich. Prima facie, od strony doktrynalnej, syntetyczne przedstawienie tego stanowiska znajduje się w Deklaracji Dominus Iesus. Jest także dobry punkt wyjścia do zrozumienia teologii „Pancernego Kardynała” jako autora tego dokumentu. Wychodząc od fragmentu, deklaracja Nostra aetate stwierdza, że

Kościół katolicki nic nie odrzuca z tego, co w religiach owych [niechrześcijańskich - OS] prawdziwe jest i święte. Ze szczerym szacunkiem odnosi się do owych sposobów działania i życia, do owych nakazów i doktryn, które chociaż $\mathrm{w}$ wielu wypadkach różnią się od zasad przez niego wyznawanych i głoszonych, nierzadko jednak odbijają promień owej Prawdy, która oświeca wszystkich ludzi ${ }^{5}$.

W tym krótkim fragmencie da się wyczuć postawę, którą roboczo można opisać zwrotem primus inter pares.

Pojawia się tu problem, z punktu widzenia katolickiego teologa mało dostrzegalny, rzeczywistej relacji wiary chrześcijańskiej do religii niechrześcijańskich. Czy Kościół uznając, że Chrystus jest jedynym zbawicielem człowieka, nie wysuwa się na pierwsze miejsce? Czy wszyscy są wówczas rzeczywiście pares - równi sobie? Jak w pluralizmie religijnym mówić o ostatecznym i całkowitym charakterze prawdy chrześcijaństwa?

Pozycja wiary chrześcijańskiej w historii religii umożliwia dwojaką postawę wobec innych tradycji religijnych: (a) można uważać je za tymczasowe i pozytywne, w tym sensie, że prekursorskie w stosunku do chrześcijaństwa; albo (b) można też uznać je za niewystarczające, przez co sprzeczne z chrześcijaństwem i prawdą, gdyż oferują nadzieję zbawienia, której człowiek nigdy nie dostąpi ${ }^{6}$.

5 Sob. Wat. II, Dekl. Nostra aetate, 2.

${ }^{6}$ Zob. J. Ratzinger, Wiara-Prawda-Tolerancja. Chrześcijaństwo a religie świata, Kielce 2005, s. 17. 
W Dominus Iesus dominuje pierwsza postawa. Deklaracja rozróżnia zatem: (a) wiarę teologalną, oznaczającą przyjęcie przez łaskę prawdy objawionej, która pozwala przeniknąć i zrozumieć tajemnicę, oraz (b) wierzenia w innych religiach, które jako owoc doświadczeń i przemyśleń stanowią skarbnicę ludzkiej mądrości i religijności, wypracowaną w drodze poszukiwania prawdy?

Historycznie zagadnienie relacji Kościoła i innych religii do zbawienia można rozwiązać za pomocą trzech teorii: ekskluzywizmu, inkluzywizmu i pluralizmu'. Mają one długą historię i były szeroko analizowane i komentowane. Warto tu jednak zaznaczyć, że Ratzinger stoi na stanowisku zgodnym z nauczaniem Soborów, przyjmując, że zbawienie ma strukturę kościelną i dokonuje się przez pośrednictwo Kościoła oraz jest dostępne wszystkim ludziom ${ }^{9}$. Kościół jawi się więc jako sakrament zbawienia i jako taki stanowi odpowiedź na szukanie jedności przez ludzkość w dzisiejszych czasach ${ }^{10}$.

Dominus Iesus wyraża przekonanie, że wierze katolickiej sprzeciwia się „postrzeganie Kościoła jako jednej z dróg zbawienia, istniejącej obok innych, to znaczy równolegle do innych religii, które miałyby uzupełniać Kościół, a nawet mieć zasadniczo taką samą jak on wartość, zmierzając co

7 Kong. Nauki Wiary, Dekl. Dominus Iesus. O jedyności i powszechności zbawczej Jezusa Chrystusa i Kościoła, 7. Ratzinger w tym fragmencie Deklaracji odwołuje się do słów Jana Pawła II zapisanych w Fides et ratio. Fakt ten uwidacznia, z jednej strony, spójność nauczania Kościoła, a z drugiej jedność w rozumieniu dialogu ekumenicznego u obu tych teologów. Szerzej na temat problemów, jakie otworzyła deklaracja na gruncie założeń ekumenizmu, zob. M. J. Rainer (red.), „Dominus Iesus”. Anstößige Wahrheit oder antsößige Kirche?, Münster-Hamburg-London 2001; M. Rusecki (red.), Wokół Deklaracji Dominus Iesus, Lublin 2001. Szerzej na temat dialogu międzyreligijnego u Jana Pawła II pisze Z. Kaźmierczak, Samoprzezwyciężenie i impulsywność myśli. O pewnej właściwości dialogu międzyreligijnego u Jana Pawła II, „Przegląd Religijny” 1 (2012) (243), s. 91-104.

${ }^{8}$ Nie mam zamiaru przedstawiać w tym miejscu skomplikowanych dziejów sporów między tymi tradycjami. Szerzej na temat trzech postaw zob. J. Ratzinger, Wiara-Prawda-Tolerancja, s. 41-45, 66-70.

9 J. Ratzinger, Pojęcie Kościoła i kwestia członkostwa w Kościele, JROO, t. VIII, s. $280-281$.

${ }^{10}$ Szerzej na temat tego zagadnienia zob. J. Ratzinger, Kościół - Powszechny sakrament zbawienia w Chrystusie, JROO, t. VIII, s. 187-257. 
prawda tak jak on ku eschatologicznemu Królestwu Bożemu” ${ }^{11}$. Deklaracja wskazuje prekursorski charakter ${ }^{12}$ innych religii, „ponieważ stwarzają pewne sytuacje lub są formami pedagogii, dzięki którym ludzkie serca zostają pobudzone do otwarcia się na działanie Boże". Nie oznacza to jednak postawy wrogości wobec innych religii, lecz odrzucenie indyferentyzmu religijnego ${ }^{13}$.

Misyjność Kościoła w gruncie rzeczy zakłada ekskluzywność jego wspólnoty ${ }^{14}$. W przeciwnym razie, gdy każdy, bez ograniczeń mógłby się do niej przyłączyć, decyzja ta nie wymagałaby nawrócenia. Pluralizm natomiast wyklucza istnienie wspólnoty. Misja Kościoła polega więc na jednoczeniu, ponownym zgromadzeniu rozproszonych członków ludzkości w jedno ciało, którego głową jest Chrystus. W tym kontekście misja ad gentes zachowuje swoją aktualność, gdyż zgodnie z założeniami wiary katolickiej Bóg pragnie zbawienia wszystkich ludzi i chce, aby poznali prawdę. W teologii Ratzingera poznanie prawdy jest drogą do zbawienia ${ }^{15}$. Ponieważ Kościół jest powiernikiem prawdy, traktuje siebie jak przewodnika wychodzącego naprzeciw tych, którzy jej szukają. Częścią Jego misyjnej natury jest dialog, a jego podstawą jest równość. Dla Ratzingera wyraża się ona w równej godności osobistej partnerów, nie biorąc pod uwagę ani treści doktrynalnych, ani osoby Jezusa Chrystusa ${ }^{16}$.

11 Kong. Nauki Wiary, Dekl. Dominus Iesus, 21.

12 Tamże: „Z pewnością, różne tradycje religijne zawierają i ofiarowują elementy religijności, które pochodzą od Boga i stanowią część tego, co »Duch Święty działa w sercach ludzi i w dziejach narodów, w kulturach i w religiach «. W istocie niektóre modlitwy i niektóre obrzędy innych religii mogą przygotowywać na przyjęcie Ewangelii, [...]. Nie można im jednak przypisywać pochodzenia Bożego oraz zbawczej skuteczności ex opere operato, właściwej chrześcijańskim sakramentom. Z drugiej strony nie należy zapominać, że inne obrzędy, jako związane z przesądami lub innymi błędami (por. 1 Kor 10,20-21), stanowią raczej przeszkodę na drodze do zbawienia”.

13 Tamże, 22.

${ }^{14}$ Ratzinger ujmuje to w taki sposób: „Misje znajdują się niewątpliwie w relacji do zbawienia i prowadzi się je ze względu na zbawienie”, zob. J. Ratzinger, Pojęcie Kościoła i kwestia członkostwa w Kościele, s. 281.

${ }^{15}$ Kong. Nauki Wiary, Dekl. Dominus Iesus, 22: „Bóg pragnie zbawienia wszystkich poprzez poznanie prawdy. Zbawienie znajduje się w prawdzie”.

16 Tamże: „Równość, będąca podstawą dialogu, dotyczy równej godności osobistej partnerów, nie zaś treści doktrynalnych ani tym bardziej Jezusa Chrystusa - Boga, który stał się człowiekiem - w odniesieniu do założycieli innych religii. Kościół bowiem, 
Znakiem dialogu w misji ad gentes jest wydarzenie Pięćdziesiątnicy, cud rozumienia dokonany $\mathrm{w}$ miłości ${ }^{17}$. Dlatego też określenie Kościoła jako przewodnika w miłości, a nie pierwszego wśród równych bardziej oddaje Jego pozycję w świecie. Jeżeli natomiast uwzględni się chrystologiczną tezę ${ }^{18}$, zgodnie z którą Jezus objawił ludziom jedyną prawdę, Kościół w świecie jawi się jako znak wskazujący drogę.

Biorąc pod uwagę powyższe stwierdzenia, można wyprowadzić pierwszy wniosek. Dla Ratzingera wiara chrześcijańska nie jest religią primus inter pares. Z jego założenia o prawdziwości objawienia wynika, że Kościół jako powiernik prawdy jest „prawdziwym drogowskazem”19 dla ludzkości. Dlatego Kościół jest w teologii Ratzingera znakiem wśród narodów. Jest to znak wskazujący drogę do prawdy, która skrywa się poza tym, co przyziemne ${ }^{20}$. Drogą do niej nie jest jednak przemoc, lecz dialog w miłości ${ }^{21}$.

powodowany miłością i poszanowaniem wolności, musi troszczyć się przede wszystkim o przepowiadanie wszystkim ludziom prawdy, objawionej w sposób definitywny przez Pana, oraz o głoszenie konieczności nawrócenia się do Jezusa Chrystusa i zjednoczenia się z Kościołem przez chrzest i inne sakramenty, co jest warunkiem pełnego uczestnictwa w komunii z Bogiem Ojcem, Synem i Duchem Świętym. Zresztą przekonanie o powszechności woli zbawczej Boga nie umniejsza, lecz wzmaga powinność i konieczność przepowiadania zbawienia i nawrócenia do Pana Jezusa Chrystusa”.

17 Zob. J. Ratzinger, Pojęcie Kościoła i kwestia członkostwa w Kościele, s. 281.

18 Ratzinger nie tylko w Deklaracji uzasadnia pozycję Kościoła w świecie przez odwołanie się do pojęć chrystologii. Dla niemieckiego teologa objawienie dokonane w Chrystusie jest nie tylko przełomem natury w kierunku ducha, lecz ukazuje sens historii świata i jej cel, którym jest zjednoczenie wszystkich rzeczy z Bogiem. Szerzej na ten temat pisze J. Ratzinger, Kościót - znak wśród narodów, JROO, t VIII, s. 957-959.

19 Kong. Nauki Wiary, Dekl. Dominus Iesus, 23. Ratzinger używa tu sformułowania Jana Pawła II z encykliki Fides et ratio.

${ }^{20}$ J. Ratzinger, Kościół - znak wśród narodów, s. 952: „Jako wspólnota stołu Bożego i sieć komunikacji, obejmująca ziemski krąg, ma on swą specyficzną widzialność i porządek, które stawiają go ponad wszelką widzialną rzeczywistość; jest 'sakramentem', który nie zamyka się w sobie samym, gdyż jego istota polega na wskazywaniu poza siebie, na Tego, który go powołał i do którego chce doprowadzić z powrotem całą historię”.

${ }^{21}$ Misja ad gentes, do której należy ów dialog, jest „widzialnym gestem otwartości Kościoła, bycia dla drugiego” (tamże, s. 959), co jakby zawiera się w sensie miłości jako takiej. 


\section{DIALOG RELIGIl22}

Dążenia wiary chrześcijańskiej w odniesieniu do zbawienia wyrażają się w starożytnym zdaniu extra ecclesiam nulla salus ${ }^{23}$. Jeżeli jednak uwzględni się postulat misyjności, z którego wynika, że głoszenie orędzia w drodze do pogan można, w pewnym uproszczeniu, nazwać Kościołem ${ }^{24}$, to wówczas okazuje się, iż cechą wiary chrześcijańskiej jest dążenie do uniwersalności. Rozważania dotyczące misji powierzonej Apostołom przez Chrystusa podkreślają ten element. Spotkanie chrześcijaństwa z religiami świata wymusiło niejako pytanie o jego istotę, które ostatecznie uniemożliwia stworzenie wspólnego pojęcia religii ${ }^{25}$.

Dla Ratzingera to właśnie misyjny charakter wiary chrześcijańskiej stanowi punkt wyjścia $\mathrm{w}$ refleksji nad religiami Wschodu, w tym także nad religią buddyzmu. Ponadto jej dążenie do uniwersalności ukazuje różnice w pojmowaniu obrazu Boga, co może okazać się kluczowe w zrozumieniu tematu i wyjaśnieniu absolutnego charakteru chrześcijańskiej drogi zbawienia. Ratzinger przyjmuje w pewnym uproszczeniu, że „religie powszechne" dzielą się na przeciwstawne typy: teistyczny i mistyczny ${ }^{26}$. Cechą charakterystyczną religii mistycznych jest ich nieokreśloność pod względem treści. Wykluczają one konflikt $\mathrm{z}$ rozumem naukowym przez to, iż ich teologia apofatyczna nie jest określona od strony pozytywnotreściowej, a religie te poprzestają jedynie na doświadczeniu mistycznym. Ich racjonalność określa się przez rezygnację z roszczeń poznawczych, co

${ }^{22} \mathrm{Na}$ temat dialogu międzyreligijnego w teologii Ratzingera zob. G. Bachanek, Uwagi Josepha Ratzingera na temat dialogu religii, „Warszawskie Studia Teologiczne” 20 (2007) 1, s. 219-228.

${ }^{23}$ Kwestię interpretacji tej formuły wyjaśnia w krótkim szkicu J. Ratzinger, Poza Kościołem nie ma zbawienia?, JROO, t. VIII, s. 975-999.

${ }^{24}$ J. Ratzinger, Problem absolutności chrześcijańskiej drogi zbawienia, s. 972.

25 Tamże, s. 961-962.

${ }^{26}$ J. Ratzinger, Dialog religii i stosunki żydowsko-chrześcijańskie, JROO, t. VIII, s. 1043-1044. Ratzinger na ich podstawie wskazuje trzy możliwe drogi dla ekumenii religii: włączenie typu teistycznego do typu mistycznego, jako szerszego; droga odwrotna; oraz droga tzw. pragmatyczna, zgodnie z którą wszystkie religie mają uznać za swój cel ortopraksję, zarzucić spory o prawdę i dążyć wspólnym wysiłkiem do pokoju na świecie. 
czyni je ze swej istoty tolerancyjnymi. Mogą one jednak nadal dostarczać człowiekowi nadziei na przekroczenie ograniczeń bytu ${ }^{27}$.

Jeżeli więc dialog religijny miałby zmierzać do uznania równorzędności poszczególnych uczestników, to musiałby on w konsekwencji zrezygnować z twierdzeń pozytywnych, czyli roszczących sobie pretensję do prawdy. Nie ma wówczas znaczenia, czy Absolut pojmuje się osobowo, czy nieosobowo, gdyż mówiący Bóg i milcząca głębia bytu określałyby dwa odmienne sposoby myślenia o rzeczywistości, niedającej się uchwycić $\mathrm{w}$ pojęciach ${ }^{28}$. Utożsamienie obydwu dróg albo redukcja do drogi mistycznej pozbawia świat materialny odniesienia, tj. relacji do rzeczywistości boskiej. Ostatecznie więc odrzucone zostaje pojęcie stworzenia ${ }^{29}$.

Na tle powyższych konsekwencji można wskazać zasadniczą cechę religii teistycznych. Jest nią nie tylko uznanie woli Bożej i zatopienie się w Bogu, lecz przede wszystkim afirmacja człowieka i jego zdolności - siły rozumu, uczuć i woli. Do tak określonej wiary należy także wysiłek na rzecz treściowo określonej prawdy ${ }^{30}$.

W tym miejscu, po raz kolejny, okazuje się, że religie nie mogą być sobie równe (pares). Potrzebna jest oczywiście swobodna dyskusja oraz poszanowanie tradycji innych dróg, lecz nie można oczekiwać, że religie wspólnie będą realizowały chociażby polityczne cele, jak na przykład pokoju na świecie. Takie podejście umniejsza ich rangę i degraduje Boga do roli bożka, służącego celom człowieka ${ }^{31}$. Wysiłek na rzecz misji, której celem byłoby zjednoczenie wszystkich ludzi w miłości ku jednemu Bogu, jest nie tylko trudniejszy, lecz jest także zadaniem wiary chrześcijańskiej ${ }^{32}$.

Jaki jest zatem warunek dialogu religijnego? Spotkanie religii może odbyć się jedynie na drodze szukania prawdy. Ratzinger ujmuje to tak: „Rezygnacja z prawdy i z przekonań nie wynosi człowieka na wyższy poziom, lecz doprowadza go do oceniania wszystkiego wyłącznie pod kątem przydatności i odziera go z jego wielkości”33. W tym wysiłku

\footnotetext{
27 Tamże, s. 1045.

28 Tamże.

29 Tamże, s. 1046.

30 Tamże, s. 1047.

31 Tamże, s. 1048.

32 Tamże.

33 Tamże, s. 1053.
} 
ważny jest szacunek dla wiary drugiego i otwartość na obecność prawdy $\mathrm{w}$ tym, co jest obce ${ }^{34}$. Tylko w ten sposób można dążyć do oczyszczenia własnej religii ${ }^{35}$ przez „gotowość przełamywania własnego zbyt ciasnego rozumienia prawdy, w przekonaniu, że swoje stanowisko lepiej poznam, jeśli zrozumiem drugiego i w ten sposób zdecyduję się na poszukiwanie większego Boga, mając pewność, że prawda o Bogu nigdy nie znajdzie się cała w moich rękach i wobec niej zawsze będę uczniem, do niej zawsze będę pielgrzymował na drodze, która nie ma końca”36.

\section{OSOBOWY ABSOLUT A OSOBISTA NIEWYSTARCZALNOŚĆ}

Ratzinger zauważa, że człowiek osiąga zbawienie nie poprzez system i skrupulatne wypełnianie jego zasad. Drogą do zbawienia jest coś, „co stanowi otwieranie się wszystkich systemów: wiara i miłość, które kładą kres egoizmowi i niszczącej człowieka pysze”. Dlatego „Religie pomagają w zbawieniu w takim stopniu, w jakim umacniają w takiej postawie; stanowią przeszkodę na drodze do zbawienia, jeśli utrudniają człowiekowi osiąganie tej postawy”37. Ze względu jednak na fakt, iż „w każdej ludzkiej miłości istnieje osad egoizmu, który ją psuje, a w końcu czyni niewystarczającą"38, człowiek potrzebuje działania Boga, w odniesieniu do którego

${ }^{34}$ J. Ratzinger, Braterstwo, JROO, t. I, s. 601: „[...] braterstwo wobec tych, którzy są na zewnątrz, często musi przejawiać się w tolerancji, dającej się określić jako szacunek dla odmienności drugiego i dla tajemnicy, którą Bóg z nim dzieli”.

${ }^{35}$ Ratzinger wskazuje, że koniecznym warunkiem dialogu religijnego jest krytycyzm, rozumiany jako szukanie czegoś pozytywnego w drugim, który staje się w ten sposób pomocnikiem w szukaniu prawdy. Religii bowiem, przy całym jej bogactwie, grozi także niebezpieczeństwo minięcia się z jej istotą. Może stać się niszcząca, jeżeli odcina człowiekowi drogę do prawdy: por. J. Ratzinger, Dialog religii i stosunki żydowsko-chrześcijańskie, s. 1054. J. Ratzinger, Braterstwo, s. 600, zaznacza, że cechą charakterystyczną katolika jest otwartość: „katolik powinien pamiętać, że być katolikiem znaczy przekraczać granice i dążyć do całości, że autentyczna tożsamość katolika przejawia się w tej właśnie otwartości”.

36 Tamże, s. 1053.

37 J. Ratzinger, Poza Kościołem nie ma zbawienia?, s. 994.

38 Tamże, s. 995. O miłości jako sposobie poznania zob. J. Szymik, Kochać znaczy widzieć. Wokót teologicznej epistemologii J. Ratzingera/Benedykta XVI, „Roczniki Teologii Dogmatycznej" 59 (2012) 3, s. 153-166. 
może uznać swoją niewystarczalność. W przeciwnym razie zamyka się w swoich partykularyzmach.

Zgodnie z wiarą chrześcijańską Bóg poprzez fakt wcielenia i osobę Jezusa Chrystusa nie pozostał sam w akcie zbawiania, lecz rozszerzył to dzieło o człowieka ${ }^{39}$. Jego zadaniem jest włączenie się w proces zbawczy innych ludzi, aby przez to działanie osiągnąć zbawienie niejako dla innych i przez innych ${ }^{40}$. Tak rozumiany akt zbawczy jawi się jako dialog, nie tylko Boga z człowiekiem, lecz także człowieka z Bogiem oraz człowieka z człowiekiem. Cecha ta wskazuje na specyficzny obraz Absolutu, który w tej wierze jest Kimś, jest Osobą ${ }^{41}$. Jest to aspekt specyficznie chrześcijański, odróżniający chrześcijaństwo od religii niechrześcijańskich, w których zbawienie osiąga się przez dążenie do osobistego szczęścia i wyzwolenia z okowów ciała i świata, aby rozpłynąć się w nieosobowym absolucie.

Co oznacza ten osobowy charakter, tak ważny dla religii teistycznej? Zdaniem Kardynała oznacza on, że

nie tylko my możemy Go doświadczyć poza wszelkim doświadczeniem, że On sam się może wypowiedzieć, komunikować. Gdzie Bóg, jak w buddyzmie, nie ma nic wspólnego z bytem osobowym, lecz stanowi czyste zaprzeczenie wszystkiego, co nam się rzeczywiście ukazuje i jawi, tam nie może być mowy o pozytywnej relacji 'Boga' do świata. W takim ujęciu świat jako źródło cierpienia ludzie mają przezwyciężyć, a nie kształtować. Religia wskazuje im drogi przezwyciężania świata, wyzwalania się od ciężaru jego pozornego istnienia - nie mówi, jak człowiek może żyć w świecie, nie ukazuje mu form wspólnotowej odpowiedzialności w świecie ${ }^{42}$.

Takie rozumienie Absolutu ma przynajmniej kilka konsekwencji dla doktryny religijnej. Stanowią one zarazem rozwiązanie postawionego

39 J. Ratzinger, Poza Kościołem nie ma zbawienia?, s. 996: „[...] Chrystus zbawia sam, to prawda, jednak ten sam zbawiający Chrystus nigdy nie jest sam i specyficzną cechę Jego zbawczego czynu stanowi to, że drugiego człowieka nie czyni po prostu biernym odbiorcą całego gotowego daru, lecz włącza go w swoje działanie”.

40 Tamże.

${ }^{41}$ Szerzej na temat obrazu Boga w teologii Ratzingera zob. J. Szymik, Obraz Boga w teologii J. Ratzingera/Benedykta XVI, "Śląskie Studia Historyczno-Teologiczne” 44 (2011) 2, s. 435-449.

${ }^{42}$ J. Ratzinger, Wprowadzenie w chrześcijaństwo, przeł. Z. Włodkowa, Kraków 2012, s. 19. 
we wstępie problemu. Świadczą ponadto o racjonalności wiary, która czci Boga jako kogoś absolutnego i do kogo wyznawcy mają dostęp poprzez akty rozumu.

Po pierwsze, pojęcie osoby jest kategorią filozoficzną, stanowiącą podstawowe ujęcie analogii między Bogiem a człowiekiem ${ }^{43}$. Za sprawą chrześcijańskiej doktryny o Trójcy Świętej wydobyto pojęcie relacji i przedstawiono Boga jako relatio subsistens. Jeżeli mówi się więc o człowieku jako obrazie Boga, znaczy to, że jest on istotą relacyjną ${ }^{44}$. Przezwyciężono tym samym niedostępność, którą charakteryzował się Bóg filozofów ${ }^{45}$. Wiara w dostępność Absolutu i w jego własną zdolność komunikacji jest także tym, co odróżnia religie teistyczne, ściślej monoteistyczne, od religii mistycznych. Pierwsze zdanie wiary chrześcijańskiej - „Bóg jest” - ma znaczenie głęboko egzystencjalne. Przyjęcie, że osobowy Bóg jest Bogiem Jedynym, porządkuje rzeczywistości.

Na tym tle ujawnia się racjonalność wiary chrześcijańskiej. Religie Azji, w tym buddyzm, próbując zmierzyć się z problemem politeizmu uświadomiły sobie, że w „bóstwach” nie czczą „Boga”, czyli czegoś absolutnie ostatecznego. Ratzinger ujmuje to tak: „Azjatycka religijność dodaje tu jeszcze: cała pozytywna religijność ma charakter czegoś przedostatniego, a ostateczny wymiar może mieć tylko negacja, czyste 'nie', rozumiane jako negacja elementów przedostatnich i wejście w sferę tego, co ostateczne" ${ }^{\text {"46. }}$. Jeśli tak, to pozytywne akty religijne, kierowane do rzeczywistości nie ostatniej, lecz przedostatniej, nie mogą mieć w konsekwencji charakteru ostatecznego. Tym samym ujawnia się linia demarkacyjna między wiarą chrześcijańską a religią mistyczną i dochodzi do rozstrzygnięcia problemu

${ }^{43}$ J. Ratzinger, Wielość religii a jedno przymierze, JROO, t. VIII, s. 1038.

${ }^{44}$ Tamże, s. 1039: „Chrześcijańska doktryna Trójcy Świętej wydobyła relacje ze schematu »substancja-przypadłość«. Sam Bóg jest teraz przedstawiany jako trynitarna struktura relacji, jako relatio subsistens. Jeśli o człowieku mówimy, że jest obrazem Boga, to znaczy, że jest istotą relacyjną; że przez wszystkie swe relacje i w nich szuka tej relacji, która stanowi podstawę jego egzystencji. Dlatego przymierze byłoby odpowiedzią na podobieństwo człowieka do Boga; w przymierzu okazywałoby się, kim i czym jesteśmy my sami, i kim jest Bóg. Dla Boga, który cały jest relacją, przymierze nie byłoby czymś zewnętrznym, pojawiającym się w historii i nienależącym do Jego istoty, lecz objawieniem siebie samego, »blaskiem Jego oblicza«".

${ }^{45}$ Tamże, s. 1038.

${ }^{46}$ J. Ratzinger, Problem absolutności chrześcijańskiej drogi zbawienia, s. 967. 
Bytu absolutnego. Prymat Logosu jest równoznaczny z pozbawieniem charakteru absolutnego wszystkich innych bożków. Wyrzeczenie się ich umieszcza we względnej perspektywie wszystko to, co nie jest Bogiem i osobą ${ }^{47}$. Ratzinger pisze, że w religiach mistycznych

Świat (a wraz z nim człowieka i wszelki byt osobowy) pojmuje się jako skończony przejaw Nieskończonego, jako pozór, nie zaś jako byt. [...] Skoro świat jest tylko pozorem, to w końcu jest właściwie niczym w zestawieniu z jedynym Absolutem, który jest jedyną rzeczywistością. Pozostaje tożsamość jednego tylko rzeczywistego bytu, od którego oddziela nas jedynie czczy pozór. W ten sposób w całym swym radykalizmie ukazuje się sprzeczność $\mathrm{z}$ wiarą Izraela [tym samym z wiarą chrześcijańską przyp. aut.]. Między Jahwe a jego stworzeniem nie ma tożsamości [... ${ }^{48}$.

Absolut rozumiany jako numen personale nie jest immanentną siłą płodności czy potężną koncentracją boskiej tajemnicy świata, lecz jest jego Stwórcą. Konsekwencją przyjęcia tej tezy jest uznanie Absolutu za zwieńczenie bytów oraz i przyznanie Jemu władzy nad rzeczywistością stworzoną ${ }^{49}$. Innymi słowy, przyjęcie założenia, zgodnie z którym świat pochodzi od Logosu, od Stwórczego sensu, oznacza, że zawiera w sobie logos - logikę ${ }^{50}$ Świat i człowiek mają swoje źródło w Logosie Boga. Dlatego wiara rodzi się ze słuchania, to znaczy z przyjęcia tego, czego sam jako człowiek nie wymyśliłem. Ukierunkowanie na Słowo ujawnia jej logocentryczność, a to znaczy, że odwraca postmodernistyczny paradygmat myślenia „ja jestem” i kieruje w stronę paradygmatu „Ty”. Wskazuje, że to nie człowiek jest punktem odniesienia i źródłem prawdy, lecz Logos - Rozum, nadający sens rzeczywistości materialnej. Zatem wiara,

47 Szerzej na temat prymatu Boga w teologii Ratzingera zob. J. Szymik, Unum necessarium. Prymat Boga i jego konsekwencje według J. Ratzingera/Benedykta XVI, „Studia Bobolanum” 3 (2011), s. 169-190.

${ }^{48}$ J. Ratzinger, Problem absolutności chrześcijańskiej drogi zbawienia, s. 967.

49 Tamże, s. 963-964.

${ }^{50}$ Szerzej na ten temat zob. J. Szymik, Teo-logika rzeczywistości. Stwórczy Logos a „autonomia rzeczy ziemskich” w interpretacji Josepha Ratzingera-Benedykta XVI, „Etos” 100 (2012) 4, s. 189-204; tenże, Cicha oczywistość Boga. Rozumność wszechświata w teologicznym ujęciu Josepha Ratzingera/Benedykta XVI, „Śląskie Studia Historyczno-Teologiczne" 45 (2012) 2, s. 273-287. 
rodząca się ze słuchania Słowa, zyskuje cechę racjonalności ze względu na swoje źródło.

W religiach Azji natomiast aktywność należy do człowieka, dla którego decydujące są przeżycia związane $\mathrm{z}$ doświadczeniem tożsamości wszystkich bytów. Różnica wiary chrześcijańskiej polega na tym, że to Bóg jest aktywny, co wyraża się w powołaniu człowieka ${ }^{51}$. Religia, która odrzuca głębię Bytu, w której Kosmos nie jest wynikiem stworzenia, nie może tworzyć wspólnoty myśli i woli i staje się indywidualną terapią ${ }^{52}$. Stąd bliska droga, jak się wydaje, do stwierdzenia definiującego buddyzm jako autoerotyzm, czyli swego rodzaju autoafirmacja, indywidualna terapia dająca szczęście.

Spotkanie z osobowym Bogiem ma jeszcze jedną konsekwencję. Umożliwia poszukiwanie właściwej „praktyki”, korygującej „teorię” oraz ukazuje, jak ważna jest kwestia różnic między religiami ${ }^{53}$. Z tej racji ma ona charakter głęboko praktyczny.

Wniosek, jaki się tu nasuwa, jeszcze raz potwierdza, że religie nie mogą dążyć do unifikacji w ramach jednej definicji religii, przyznając wszystkim tę samą pozycję. Co za tym idzie, konieczne jest wartościowanie, tak aby nie popaść w kakofonię tak samo brzmiących różnych form religijności. Wyznacznikiem winno tu być określenie źródła, na podstawie którego określa się poziom racjonalności wiary: czy jest nim Logos - Boży rozum, w którym człowiek ma także udział, czy raczej punktem odniesienia do opisu świata jest osobiste, a zatem subiektywne przeżycie.

\section{APOLOGIA RATZINGERA - ZAMIAST ZAKOŃCZENIA}

Leo Lefebure w krótkiej analizie wskazuje, że użyte przez Ratzingera porównanie buddyzmu do autoerotyzmu mogło być owocem spotkania z dyskusją nad filozofią Plotyna, w której R. Harder użył

${ }^{51}$ J. Ratzinger, Wiara-Prawda-Tolerancja, s. 33. Takie ujęcie różnic między religiami pozwala Kardynałowi mówić o rewolucji prorockiej. Szerzej na temat tej rewolucji i różnicy między obrazem Boga zob. tamże, s. 27-37.

${ }^{52}$ J. Ratzinger, Dialog religii i stosunki żydowsko-chrześcijańskie, s. 1046.

${ }^{53}$ J. Ratzinger, Wprowadzenie w chrześcijaństwo, s. 20. 
terminu „autoerotyzm” na określenie fascynacji pięknem duszy ${ }^{54}$. W tej dyskusji znacznie częściej pojawiały się jednak określenia projektu Plotyna jako „autoerotyczny odblask” (autoerotic reflection) czy „autoerotyczna przyjemność" (autoerotic jouissance), które wprowadziła Julia Kristeva. Lefebure zauważa jednak, że bardziej prawdopodobne jest to, iż komentowane porównanie mogło być wynikiem fascynacji Ratzingera teologią Hansa Ursa von Balthasara, który interpretował neoplatoniczną mistykę chrześcijańską jako „bardziej buddyjską niż chrześcijańską”. Autor ten konkluduje, że pojęcie „duchowego autoerotyzmu” mogło mieć swoje źródło w tych opisach filozofii Plotyna i zostało przełożone nie na interpretacje buddyzmu jako takiego, lecz na jego współczesne zachodnie praktyki ${ }^{55}$.

Analiza wybranych wypowiedzi Ratzingera dotyczących buddyzmu nie potwierdza tej tezy. Próżno w nich szukać tak ostrego tonu, jaki pojawił się w wywiadzie dla francuskiej gazety. Dominuje w nich raczej troska o zachowanie racjonalnego, zgodnego z metafizyką, spojrzenia na relację człowieka do Absolutu, czyli de facto sprzeciw wobec zataczającego coraz szersze kręgi w kulturze Europy subiektywizmu i relatywizmu ${ }^{56}$. Przejawia się w nich troska o zachowanie tożsamości wiary oraz kultury europejskiej.

Kardynał Ratzinger, na co sam wyraźnie wskazuje, nie ma zamiaru budować uzasadnień zmierzających do umacniania opozycji wobec innych religii. W świecie przepełnionym pluralizmem próbuje określić miejsce wiary chrześcijańskiej na tle historii religii, głównie po to, aby poznać własną chrześcijańską drogę $e^{57}$. Od razu jednak zaznacza, niejako

54 'The term 'autoerotic' was used by the respected Plotinus scholar, Richard Harder, to describe Plotinus' presentation of the fascination of the beautiful soul for itself”. L. D. Lefebure, Cardinal Ratzinger's Comments on Buddhism, „Buddhist-Christian Studies" 18 (1998), s. 222.

55 Tamże, s. 221-223.

${ }^{56} \mathrm{~W}$ wywiadzie dla francuskiej gazety wypowiedź dotycząca buddyzmu pojawia się właśnie w kontekście zataczającego szerokie kręgi relatywizmu, który rozwija pewien rodzaj moralnej i intelektualnej anarchii: Le testament du Panzerkardinal Ratzinger (dostęp 20.10.2015).

57 J. Ratzinger, Wiara-Prawda-Tolerancja, s. 37. 
z pozycji przewodnika, że nie można zapominać, że wszystkie religie są częścią jednej historii, która różnymi drogami zmierza ku Bogu ${ }^{58}$.

Można powiedzieć, że Ratzinger nie buduje teoretycznych uzasadnień dotyczących ekskluzywności zbawienia jednych wbrew drugim. Jego tezy nie dotyczą pytania o to, czy i jak zostaną zbawieni „inni”. Dotyczą one problemu ad intra Kościoła, mianowicie odpowiedzi na pytanie: dlaczego człowiek winien wybrać chrześcijaństwo. Są to głównie wypowiedzi skierowane do chrześcijan, i nie stanowią teorii o zbawieniu niechrześcijan. Jego twierdzenia teologiczne na temat uniwersalności chrześcijaństwa mają sens jedynie w dialogu, w wysiłku szukania prawdy, by przekonać ludzi tu i teraz, że zbawienie znajdą jedynie w Prawdzie.

Streszczenie. Artykuł jest próbą uzasadnienia racjonalności religii teistycznej przez odwołanie się do wyobrażenia Absolutu w chrześcijaństwie i religiach wschodnich. Przedmiotem badań jest teologia Josepha Ratzingera, ze szczególnym uwzględnieniem wypowiedzi dotyczących buddyzmu. Przeprowadzona analiza pokazuje, że istotnym elementem odróżniającym religie teistyczne, w sposób szczególny chrześcijaństwo, od religii mistycznych jest rozumienie Absolutu. Tę ogólną tezę potwierdzają trzy zasadnicze wnioski. Po pierwsze, kluczowym elementem religii chrześcijańskiej jest pojęcie osoby, stosowane także w odniesieniu do Absolutu. Po drugie, konsekwencją przyjęcia tej tezy jest uznanie, że świat jest wynikiem stworzenia i ma swoje źródło w Logosie. Ostatni wniosek sprowadza się do uznania, że religia (a także wszystkie kultyczne formy religijności) odrzucająca ograniczenie człowieka zamyka się w partykularyzmach i w konsekwencji jest autoafirmacją.

Słowa kluczowe: teologia Ratzingera; logos; logocentryzm; Absolut; dialog religii.

${ }^{58}$ Zdanie to, po raz kolejny, może być zrozumiane jedynie wówczas, gdy uwzględni się cel tej argumentacji, to znaczy pogłębienie i zrozumienie własnej drogi. Ratzinger zaznacza, że „dla wiary chrześcijańskiej historia religii nie jest obiegiem tego, co wiecznie jest takie samo, co nigdy nie dotyka istoty rzeczy, pozostającej zawsze poza obrębem historii. Chrześcijanin bowiem uważa historię religii za prawdziwą historię; za drogę, której kierunek określa postęp, a której postawą jest nadzieja. Swoją służbę powinien on realizować jako człowiek mający nadzieję, nieomylnie zdający sobie sprawę z tego, że przez wszelkie niepowodzenia i nieporozumienia między ludźmi spełnia się cel historii - przekształcenie 'chaosu', od którego wziął swój początek świat, w wieczne miasto Jeruzalem, w którym pośród ludzi mieszka jedyny i wieczny Bóg, będący na wieki ich światłem". Tamże. 


\begin{abstract}
Religion as a spiritual autoerotism or logocentred attitude of faith? Consequences of personal understanding of Absolute in Joseph Ratzinger's theology. The aim of this paper is to reason theistic religion as rational by referring to the idea of Absolute in Christianity and Eastern religion. The subject of research concern theology of Joseph Ratzinger, in particular statements about Buddhism. The analysis shows that an important element differentiates between theistic religion, particularly Christianity and mystic religion is understanding of Absolute. This general thesis led to three main conclusions. First, one of the key elements of Christian religion is the notion of person, used also in regard to Absolute. Second, consequence of this thesis is recognition that the world is the result of creation and has its source in Logos. The last conclusion comes down to a recognition that religion (and all cultic forms of religiosity), rejecting the limitation of man, closes in particularisms and is, consequently, self-affirmation.
\end{abstract}

Key words: Ratzinger's theology; logos; logocentrism; Absolute; dialogue of religions. 